\title{
Life and Evolution: Why Theology Matters
}

\author{
Lucio Florio \\ Pontificia Universidad Católica Argentina
}

\begin{abstract}
The religions include a vision about life that has gravitated for millennia and that seems to survive, even in a time of supremacy of the scientific and technological rationality. In fact, they operate as great shapers of meaning for a large part of humanity. Particularly, the coexistence between a scientific view of the phenomenon of the life with religious understanding frames of it is a fact in many places. In effect, the religious vision continues to confer an ultimate horizon of meaning for many biologists, for a significant number of teachers in biology, as well as for a multitude of believers. There are many people who nurture their vision of life both in science and in some religious conception. For this reason, it is important the analysis of the biblical theology of life. It allows evaluating the scope of a cultural force that persists in its reading of the phenomenon of life, even coinciding with scientific visions of it. One of the aspects to understand is the inclusion of the evolutionary perspective assumed by the present Christian theology of life. The theology of evolution is one of the most significant approaches of this way of thinking about the phenomenon of the life. Moreover, in the current state of risk of the biosphere, the need to promote integrated visions becomes imperious. This is the reason to try to understand the new perspectives of the eco-theology.
\end{abstract}

Key words:

Life - Evolution - Theology - Anthropocene - Eco-theology

\section{Theology of life and Evolution}

The evolutionary vision of life has implied a varied reaction on part of Christian theology since its scientific formulation by Charles Darwin. In our time, theological reflection, after a hesitant first stage, has incorporated the evolutionary explanation in its worldview (Pascual 2005; Auletta - Leclerc - Martínez 2011; De Asúa 2009). In fact, there has been an important increase in theological publications on the evolutionary topic. In the field of the Catholic Church, this has occurred even within the scope of its official publications (Martínez 2011, 589-612).

Theology has been conceived by the Christian tradition as an understanding of the faith through the available rational resources. Therefore, to think the life as a creature today requires using the paradigm of evolution (Arnould 2010). Since the phase of the controversial debate between evolution and revelation seems to have passed, it is possible elaborate a "theology of evolution". This theology tries to integrate the evolutionary understanding of life, without concordisms, into the theological thought (Lambert 1999).

Anyway, there is still a conflict between some religious views and evolution. To be exact, the problem subsists between some different forms of creationism and the neoDarwinist interpretations. The conflict continues primarily in the North American area, although resonances elsewhere: in Europe (Arnould 2009, 357) and also in Latin America (Machado Silva et alii 2015). However, such polarization does not affect the theology elaborated in other cultural environments. For now, purely literal hermeneutics of the Bible does not predominate in the Catholic field and in much of the European 
Protestant area. But neither is the influence of biologically reductionist readings on populations of widespread popular religiosity -like Latin America or African areas, for example-, open to a religious understanding of life. On the other hand, academic scientific culture has English as its own language and it implies a gravitation of the methodological rules and problems of the Anglo-Saxon cultural milieu over the philosophical and theological perspectives of the evolution. In fact, issues such as random, finalism, body-spirit or mind-brain relationships, etc., reach other areas of thought with a link to the categories of Anglo-Saxon philosophical understanding. Moreover, some studies on the history of the connections of evolutionary ideas and the theology have shown the importance of considering biological science in its mature state of development (Ruse 2001), as well as the identification of positions not sufficiently critical in the philosophical and theological area (De Asúa 2009, 277-322).

\section{Natural theology}

The theory of evolution has challenged the classical natural theology. After Darwin, no one can naively appeal to the natural order or the beauty of creation to justify the idea of a first efficient cause. Indeed, the display of the principle of natural selection as one of the structural elements of prevents setting a bloodless natural theology. To the old idea of evil as a questioning of any idea of a perfect and good God is added that of the bloody structure of competition and predation of the vital phenomena. Darwin himself knew the version of natural theology that William Paley proposed in his time. Recently, Richard Dawkins has updated the problem through the images of a "sadistic" or "bloody God" that would emerge from the understanding of life under the prism of natural selection (Dawkins 2000, 105). Theodicy has again been harmed, not by the lacerating enigma of human evil -especially of the innocent- but by the amplification of the tragic elements of living nature. Natural theology is fragile to explain the violence of an evolution that consumes individuals, populations and entire species. The evolutionary process is full of "victims" (Peters 2007). As with the mystery of human evil, the philosophical God is, at least, a principle of insufficient understanding for this dimension of natural death. Then, for believing thought it is necessary to appeal, like Job in the Old Testament, to a less rationalistic version of God. Precisely, the inadequacy of natural theology that dispenses with the bloody evolutionary dynamic has led some theologians to rethink God under the dramatic category ${ }^{1}$.

In the recent decades, the Intelligent Design project has resumed natural theology. It admits the fact of evolution, but maintains it cannot be explained exclusively by the principle of natural selection, especially in certain complex phenomena (Arnould 2011; Brand 2011). Then, there would be a rational predetermination of the process. But, in contrast with this, according to biblical theology there would be not strictly a design, but a plan, i.e., a non-absolutely-default scheme. In other words, there would be a project or purpose (Eph 3, 11), not a design (Haught 2001, 87; Haught, 2006, 98-116; Gregersen - Görman 2001). Hence, creation could be understood as the donation of being to a living entity endowed with autonomy in the search for its forms.

In addition, the image of God of the New Testament is, on the one hand, Trinitarian, that is, a reality of communion in unity; and, on the other hand, kenotic (Phil 2,7), that

\footnotetext{
${ }^{1}$ In this perspective, see: “Theodramma and Evolution”, in: C. Deanne-Drummond 2009, 48-52.
} 
is, altruistically donated, especially on the cross. For this reason, Christian theology has no problem to consider the creation as a donated and autonomous reality. The theology can accept, without problems, that God has given up shaping every species and living individual, leaving a margin of capacity for self-organization -of certain "creativity" - to the process itself.

\section{Biblical hermeneutics}

The crisis produced by the heliocentric theory was overcome, after several centuries, by the convergence of the scientific development with a biblical hermeneutics that managed to distinguish the revealed message from the worldviews of the hagiographers. Indeed, the overcoming of the opposition between faith and natural sciences was overcome when criteria of biblical hermeneutics guided by literary and historical principles were established. In the Catholic field, the official solution came with the encyclical Divino Afflante Spiritu (1943) that established the distinctions between scientific and revealed trues. After that, the historical-critical method was formalized by the official hermeneutics as an indispensable method, although not the unique (Pontifical Biblical Comission 1993). As an indirect effect, the application of principles of hermeneutical sciences to biblical texts freed exegetes from dealing with problems established by the natural sciences, such as that of biological evolution. From then on, evolution could enter as thematic of theological research, without having to be limited to literal readings of the texts.

\section{Theological and scientific narratives of life}

There is a narrative pretension on the part of the biology and the theology. In effect, both disciplines have the intention of configuring a unitary narrative of their objects of study. Biology, on the one hand, tries to elaborate a history of the life, through a phylogenetic description that includes a semiology product: the phylogenetic tree or tree of life (O'Malley - Koonin 2011; Florio 2013). Theology, on the other hand, postulates a narrative unity of the creation, called "economy" by the patristic and, subsequently, "history of salvation". This history includes the beginning of creation as a first step, and integrates also the history of life.

Such a narrative pretension of biology and theology corresponds to an ontological topic. Indeed, biology presupposes a unity in the succession of living and humans; meanwhile, the so-called biblical revelation lies in the assumption of a unitary history of God with the world and human beings. Both ways of knowledge, then, rest on the conception of the temporal unity of their objects of reflection. Therefore, both narratives presuppose the existence of historical ontologies.

The scientific narrative, on the one hand, is based on observations and theories that make up a vision of the history of life. This narration is symbolized in semiotic formulas like those of the tree of life. Issues such as the oneness of the whole process and the characteristics of macroevolution must still be demonstrated. Anyway, the theory has a dose of empirical evidence that allows you to string together a history and, later, compose a narration of it. For its part, the biblical narrative, supported by texts that articulate a succession of facts and words of a historical subject (Israel, Church), 
interprets history from a unity conferred by a divine plan made in time. The narration of the story is plural, due to the diversity of authors, genres, etc. It has been interpreted as homogeneously within the same canonical body (see: Heb.1, 1-2) and, more markedly, in the post-biblical time. ${ }^{2}$ These narratives of the cosmos, of life, of human history and revelation allow an interdisciplinary perspective to frame the question of reality without sacrificing its historicity. But the transfer of a cosmic and human historicity to the terrain of the narrative implies the translation of a complex phenomenon, epistemologically articulated in diverse fields, to a different one, where the scientific, literary and historical categories are recomposed and integrated in a single story (Peacocke 1993, 1-2; Cardenal 1993; Jou 2009, 19-33).

\section{Trinitarian theology of evolutionary creation}

According to the Christianity, creation is the work of a Trinitarian God. Therefore, the origin and destiny of the whole process of the cosmos and life is a reality characterized by the coexistence of three "who" in the unity of the same divine entity. Thus, the beginning and the end of the universe are understood in the horizon of the interpersonal reality. And also, the network of beings in their complex interaction is considered as a reflection of its author. In fact, the structure of the beings is the referentality, to be "towards-another"; this reveals something of the absolute relationality that is God in himself. The theological concept of perichoresis reminds us that the principle of the cosmos is a communion capable of integrating multiplicity into unity.

This suggests the idea that the creation is a single project, but it houses a possibility of generating a multitude of individual and specific beings, as an effect of the Trinitarian reality. Evolution would be, in this sense, an epiphanic deployment of Trinitarian communion. The surprising successive appearance of living beings over the millions of years would emphasize the same ontological structure of God (Edwards 1991; Papanicolau 2006; Florio 2008, 153-158; Doncel 2002). In words of John Haught:

"If God is the ultimate source of order, God is no less primordially the source of novelty that sometimes has to disrupt order so as to overcome triviality and monotony. The God of evolution is the inexhaustible wellspring of new form of order" (Haught 2006, 87).

\section{Anthropology}

The question of the origin of the human being constitutes an exciting scientific debate, with philosophical and theological repercussions. The determination of the way and the moment of the appearance of humans corresponds to the paleontology. In the words of Teilhard de Chardin, the human being appeared silently in the history of life (Martelet 2007, 31). However it may have been the emergence of self-reflective and symbolic thought has been interpreted by theology as a non-gradual but essential novelty, explicable only by a new divine creative act, even in the context of a biological evolution (Ladaria 2012, 146). A hominid, or a group of them, at some point in the past million years, has reached a kind of abstracting, self-aware and symbolic thinking. This is interpreted theologically as the appearance of a spiritual dimension, characterized by

\footnotetext{
2 "...the history of the theology shows that its development is intimately related to the understanding of the natural, including the human, world that has prevailed at different periods" (Peacoke 1993, 21).
} 
its openness to the divine. In fact, according to the biblical perspective, the human being identifies himself as a "you" for God; even more, the human being is the living being in whom the divine Logos will become Homo sapiens in Jesus of Nazareth $(J n$ 1, 18). This Christological orientation of the hominization process -based on Eph 1, 3-14- leads theology to a very particular definition of what it means to be human.

The directionality or chance of the process that culminates in the human being are accentuated by different authors in one or another line. Some theologians, privileging chance as a phenomenological note determined by neo-Darwinian evolutionary biologists, point out that God has created an absolutely casual process (Haugth 2006, 52-52). The difficulty of maintaining this position in its extreme form is that a casual process could not have arrived until the appearance of a subject fit to become a "you" to the creator - something essential in biblical thought. On the other side, there are authors that extreme the directionality in a vision focused on the human being (Teilhard de Chardin 1971); but also the supporters of the Intelligent Design seem to lead the reasoning towards analogous conclusions.

The anthropological question includes some relevant issues to theology, such as the dilemma between monogenism or polygenism (Fachini 2008, 142-144; Kemp 2001, 217-236), or the original sin (Nielsen 2010). Likewise, the question of the uniqueness of man in the universe is important for the vision of the biblical tradition (Tanzella-Nitti 2002). In any case, the essence of this vision remains that the human being is the image of God (imago Dei), recipient of the Alliance and, above all, the living creature where became incarnate the Word of God (Jn 1, 14).

\section{Ecological crisis and theology}

The serious situation of this moment of the evolution of the biosphere, caused by the action of the combination of science and technology, seems to require an ethical and philosophical reflection. For this reason, an ecological philosophy and environmental ethics that consider the problem in its dimension of meaning and responsibility, have emerged. Theology has also tried to face the challenges of the ecological question. From the point of view of the biblical perspective, it proposes a consideration of life on the planet. Recently, different lines of theology have developed contributions to elaborate an "eco-theology". Some of theirs ideas are: the fraternity or solidarity of human being with the rest of the planet based on the common creative relationships -idea that has crystallized in the image of the "common house" (Francis 2015); the intergenerational justice or ecological sin; the proposals for an ecological spirituality; etc. The ecological theology is guided by the conception of a unity of creation and salvation (Papanicolau 2005; Florio 2008; Conradie 2012). It insists on the vision of the human being as an administrator of the universe, trying to modify the traditional idea that humans have a despotic task respect of the creation. The dramatic situation of the biosphere demands to the theology an effort to approach with its peculiar horizon of perspectives: it has not a technical or scientific access to the problem, but it can offer a strong frame to the ecological Ethics, especially for the believers. In our times, where there are not many strong thoughts to ground a common Ethics, theology can give certain elements to the reflection. Moreover, many inhabitants of the world are believers of different religions. Then, it is important for the universal environmental awareness that they articulate an ecological thinking. 


\section{Conclusions}

Why take into account the theology, in the age of predominance of the sciences, to think the life? It would seem that it has been definitively overcome because the sciences are solids, they have their own methods and, integrated with technology, they have shaped an autonomous vision of the world, shared by different cultures and individuals. Nevertheless, religion continues to confer an ultimate horizon of meaning to many people -including scientists and teachers in sciences-. In fact, there are many believers who nurture their vision of life both in science and in a religious conception. This is the reason to consider the religious worldviews, where scientific and theological sources are decisive. And then, hence the importance of analyzing the biblical theology of life, due its influx on Western cultures and contemporary thought. This would allow evaluating the features of a cultural force that persists in its interpretation of the phenomenon of life.

Moreover, the current state of risk of the biosphere demands the integration of the perspectives originated not only in science and technology but also in other fields of the human experiences to promote integrated visions of the Anthropocene challenges. In this sense, the theological perspective could collaborate with elements to configure a strong environment basis of a common ecological Ethics.

References:

Arnould, Jacques. 2010. "Theologians Wanted!” Some Reflections about the Creation/Evolution Debate. Theology and Science, 8:4, 357-370, DOI: 10.1080/14746700.2010.517636

Arnould, Jacques. 2011. "Creationism, Intelligent design and evolution: a theological perspective". In: Biological Evolution, Facts and Theories. A Critical Appraisal 150 Years After "The Origin of Species", eds. Auletta, Gennaro - Leclerc, Marc - Martínez, Rafael A, 573-588.

Auletta, Gennaro - Leclerc, Marc - Martínez, Rafael A. (eds.). 2011. Biological Evolution, Facts and Theories. A Critical Appraisal 150 Years After "The Origin of Species". Rome: Gregoriana \& Biblical Press.

Ayala, Francisco. 2005. "Two revolutions: Copernicus and Darwin". In: Pascual, Rafael (editor), L'Evoluzione: Crocevia di Scienza, Filosofia e Teologia. Roma: Edizione Studium.

Brand, Leonard. 2011. Fe, Razón y la Historia de la Tierra. Un paradigma de los orígenes de la Tierra y de la vida mediante un diseño inteligente. Libertador San Martín: Edit. Universidad Adventista del Plata.

Cardenal, Ernesto .1993. Cántico cósmico. Madrid: Trotta.

Conradie, E. M. 2012 . Creation and Salvation. Vol 2: A Companion on Recent Theological Movements Studies on Religion and the Environment. Münster: LIT Verlag,.

Dawkins, Richard. 2000. El río del Edén. Debate: Madrid.

Deanne-Drummond, Celia. 2009. Christ and Evolution. Wonder and Wisdom. London: SCM Press.

De Asúa, Miguel. 2009. De cara a Darwin. Buenos Aires: Lumen. 
Doncel, Manuel. 2002. "The Word as Design-Realiser for the Creation, and the Spirit as DisorderRestorer for the New Creation". In: ESSSAT, Studies in Science \& Theology 8. Gregersen, N.H. Görmanh, U. -Meisinger (eds.). Aarhus: H. University of Aarhus, 43-75.

Edwards, Dennis. 1991. The God of Evolution. A trinitarian Theology. Mahwah, NJ: Paulist Press.

Fachini, Fiorenzo. 2008. Le sfide della evoluzione. In armonia tra scienza e fede. Milano: Jaca Book.

Florio, Lucio. 2008. "Cosmic Christology and Pneumatology. Updating a Traditional Theological Topic to Approach a Dynamic Univers". In: Valdemar Cisto, Ks. - Kubacki Zbigniew (eds.), Sens Ludzkiej Prozygody. Warszawa: Wydawnictwo Rhetos, 153-158.

Florio, Lucio. 2013. "The Tree of Life. Philosophical and Theological Considerations". Studia Aloisiana, $4,15-27$.

Francis. (2015). Laudato si’. Vatican: Libreria Editrice Vaticana.

Gregersen, Niels - Görman, Ulf (eds.). 2001. Design and Disorder. Perspectives from Science and Theology. Bodmin, Corwll: T\&T Clark.

Haught, John. 2006. Responses to 101 Questions on God and Evolution. New York: Paulist Press

Haught, John. 2006. Is Nature Enough? Meaning and Truth in the Age of Science. Cambridge: Cambridge University Press.

Jou, David. 2009. Reescribiendo el Génesis. De la gloria de Dios al sabotaje del universo. Barcelona: Destino.

K.emp, K.W. “Science, Theology, and Monogenesis". In: American Catholic Philosophical Quarterly, Vol. 85 (2011), No. 2, 217-236.

Ladaria, Luis Francisco. 2012. El hombre en la creación. Madrid: BAC.

Lambert, Dominique. 1999. Sciences et théologie. Les figures d'un dialogue. Bruxelles: Presses Universitaires de Namur.

Martelet, Gustave. 2007. E se Teilhard dicesse il vero... Milano: Jaca Book.

Martínez, Rafael A. The Reception of Evolutionary Theories in the Church. 2011. In: Biological Evolution, Facts and Theories. A Critical Appraisal 150 Years After "The Origin of Species", eds. Auletta, Gennaro - Leclerc, Marc - Martínez, Rafael A, 589-612. Rome: Gregoriana \& Biblical Press, 589-612.

Machado Silva, Heslley- $\quad$ Fleury Mortimer, Eduardo- Nicolini Nabuco de Araújo, Elaine Sandra - Rodrigues da Silva, Paloma - Lopes Souza, Ana Carolina (2015). "A percepçâo no Brasil sobre a hipótese do Criacionismo da Terra Jovem". Quaerentibus. Teología y Ciencias, $\mathrm{N}^{\circ} 5$ (2015), 7-4 (http://quaerentibus.org/q05.html).

Nielsen, Marie Vejrup. 2010. Sin and Selfish Genes. Christian and Biological Narratives. Leveun-ParisWalpole: Peeters.

O'Malley, Maureen A. - Koonin, Eugen V. "How stands the Tree of Life a century and a half after The Origin?", Biology Direct (2011) 6:32.

Papanicolau, Jorge. 2006. Cristología cósmica. Buenos Aires: Epifanía. 
Pascual, Rafael (eds.). 2005. L'Evoluzione: Crocevia di Scienza, Filosofia e Teologia. Roma: Studium.

Peters, Ted. 2007. "Evolution, Evil and the Theology of the Cross". Svensk Teologisk Kvartalskrift. Ar g.. 83 (2007), 98-120.

Pontifical Biblical Comission. 1993. The Interpretation of the Bible in the Church. Vatican: Libreria Editrice Vaticana.

Peacocke, Arthur. 1993. Theology for a Scientific Age. Minneapolis: Fortress Press.

Peacocke, Arthur. 2001. Paths From Science Towards God. London: Oneworld Publications

Ruse, Michael. 2001. El misterio de los misterios. ¿Es la evolución una construcción social? Barcelona:

Tanzella-Nitti, Giuseppe (2002). "Extraterrestre, Vita". In: Tanzella-Nitti, G. - Strumia. A. (eds.), Dizionario Interdisciplinare di Scienza e Fede, T. I. Roma: Urbaniana University Press- Città Nuova, 591-605.

Teilhard de Chardin, Pierre 1971 (5th. ed.). El Fenómeno Humano. Madrid. 